\title{
Multiple Intelligences, Chronic Relative Underperformance Risk and the Perception of the Organizational Creative Environment
}

\author{
J.H. Jessurun \\ G.G. Anthonio \\ S.E.C. Gelper
}

M.C.D.P. Weggeman

\begin{abstract}
Summary
Creativity is important within knowledge intensive organisations. In this article we research the relations between profiles of multiple intelligences (Gardner, 1983), and how employees assess their organization as supporting creativeness. We are interested in whether different types of person look differently upon the organization in this regard. Special attention is given to the discrepancy that profiles of intelligences may have in relation to the requirements of their jobs, a misfit which gives risk for chronic relative underperformance (Jessurun et al., 2020), and how these relate to the assesment of the work environment. Results show that there is mild support for our expectation that multiple intelligences do matter, and that employees with profiles that are high on intelligences not required for the job, do indeed assess the work environment as less beneficial for creative output. It is concluded that organisations (which consists of a spectrum of differently profiled humans) may benefit from taking into account these differences within their workforce.
\end{abstract}

\section{Introduction}

Creativity is an important asset in organizations; innovation depends on it (Amabile, 2006; Amabile et al., 1996; Mumford \& Simonton, 1997). The subject of interest in this article is Multiple Intelligences (MI) as intelligence, skills and abilities representations, and how differences in profiles of multiple intelligences relate to what people perceive in their organization as supporting or hampering creativeness in their organization. The question we explore in this article is, whether people with different 'profiles of intelligence' need different things from their work context. We 
think that these different needs manifest themselves in how they perceive the organization as supporting these needs. This leads to the next statement we want to explore:

Individuals with different multiple intelligence profiles perceive the organizational climate regarding support of creativity differently.

According to Mumford \& Simonton (1997), creativity and innovation are essential requirements for organizational success, especially in a dynamic global economy. However, they state, creativity has not been seen as a factor to include when designing an organization. Creativity is not only a personal thing, but it has to land within the right conditions to make innovation possible (Amabile, 2006). Gardner (1993) states, that you can only be creative in a domain once you have attained a level of proficiency. People working in organizations have all kinds of attributes, some are necessary for their jobs, others are less so, in some cases they have too high a level of certain attributes, and sometimes they can just cope. So for each person there is a fit between their jobs and their attributes, which is captured by the Person-Environment Fit theory by Edwards and co-workers (Edwards et al., 1998; Edwards \& Shipp, 2007).

To be creative employees needs to be proficient. They must have higher skills and abilities to solve problems, make products or deliver services within the domain; or in other words, they must be more intelligent in it, following the definition of intelligence within the multiple intelligences theory (Gardner, 1983, 1993, 2002). Multiple intelligences theory states, that there is more to intelligence than those abilities measured by traditional IQ tests, and Gardner (1983) stated that there are several intelligences, set eight criteria for a set of abilities to constitute an intelligence, and based on this, he proposed eight intelligences (Gardner, 1983, 1993). These are described in Table 1. Two of the criteria are, that the intelligence must be independent of all others, and that there must be an evolutionary value for the intelligence. These two criteria, and the fact that over the years no other candidates beyond the eight mentioned have qualified (such as creative intelligence, spiritual intelligence (Gardner, 2000), existential intelligence), suggests that everything we do in life is done using a combination of the eight intelligences now included in the model. 


\section{Table 1}

Description of the eight intelligences

\begin{tabular}{|c|c|}
\hline Intelligence & Description \\
\hline Linguistic & $\begin{array}{l}\text { To think in words and to use language to express and understand complex } \\
\text { meanings. Sensitivity to the meaning of words and the order among words, } \\
\text { sounds, rhythms and inflections. To reflect on the use of language in every day } \\
\text { life. }\end{array}$ \\
\hline $\begin{array}{l}\text { Logical- } \\
\text { Mathematical }\end{array}$ & $\begin{array}{l}\text { To think of cause and effect connections and to understand relationships among } \\
\text { actions, objects or ideas. To calculate, quantify or consider propositions and } \\
\text { perform complex mathematical or logical operations. It involves inductive and } \\
\text { deductive reasoning skills as well as critical and creative problem-solving. }\end{array}$ \\
\hline Visual-Spatial & $\begin{array}{l}\text { To think in pictures and to perceive the visual world accurately. To think in three } \\
\text { dimensions and to transform one's perceptions and re-create aspects of one's } \\
\text { visual experience via imagination. To work with objects effectively. }\end{array}$ \\
\hline Musical & $\begin{array}{l}\text { To think in sounds, rhythms, melodies and rhymes. To be sensitive to pitch, } \\
\text { rhythm, timbre and tone. To recognize, create and reproduce music by using an } \\
\text { instrument or voice. Active listening and a strong connection between music and } \\
\text { emotions. }\end{array}$ \\
\hline Kinesthetic & $\begin{array}{l}\text { To think in movements and to use the body in skilled and complicated ways for } \\
\text { expressive and goal directed activities. A sense of timing, coordination for } \\
\text { whole body movement and the use of hands for manipulating objects. }\end{array}$ \\
\hline Interpersonal & $\begin{array}{l}\text { To think about and understand another person. To have empathy and recognize } \\
\text { distinctions among people and to appreciate their perspectives with sensitivity to } \\
\text { their motives, moods and intentions. It involves interacting effectively with one } \\
\text { or more people in familiar, casual or working circumstances. }\end{array}$ \\
\hline Intrapersonal & $\begin{array}{l}\text { To think about and understand one's self. To be aware of one's strengths and } \\
\text { weaknesses and to plan effectively to achieve personal goals. Reflecting on and } \\
\text { monitoring one's thoughts and feelings and regulating them effectively. The } \\
\text { ability to monitor one's self in interpersonal relationships and to act with } \\
\text { personal efficacy. }\end{array}$ \\
\hline Naturalistic & $\begin{array}{l}\text { To understand the natural world including plants, animals and scientific studies. } \\
\text { To recognize, name and classify individuals, species and ecological } \\
\text { relationships. To interact effectively with living creatures and discern patterns of } \\
\text { life and natural forces. }\end{array}$ \\
\hline
\end{tabular}

Adapted from Shearer (1996) 
The pathway from the skills and abilities to its expression has been described in the Universal Model of Giftedness (UMG) (Jessurun et al., 2016), which is an adaptation of the Munich Model of Giftedness (Heller, 2004; Heller \& Hany, 1986), using the multiple intelligences model as its input side. In this model neither the moderators mentioned nor the outcome variables are an exhaustive enumeration.

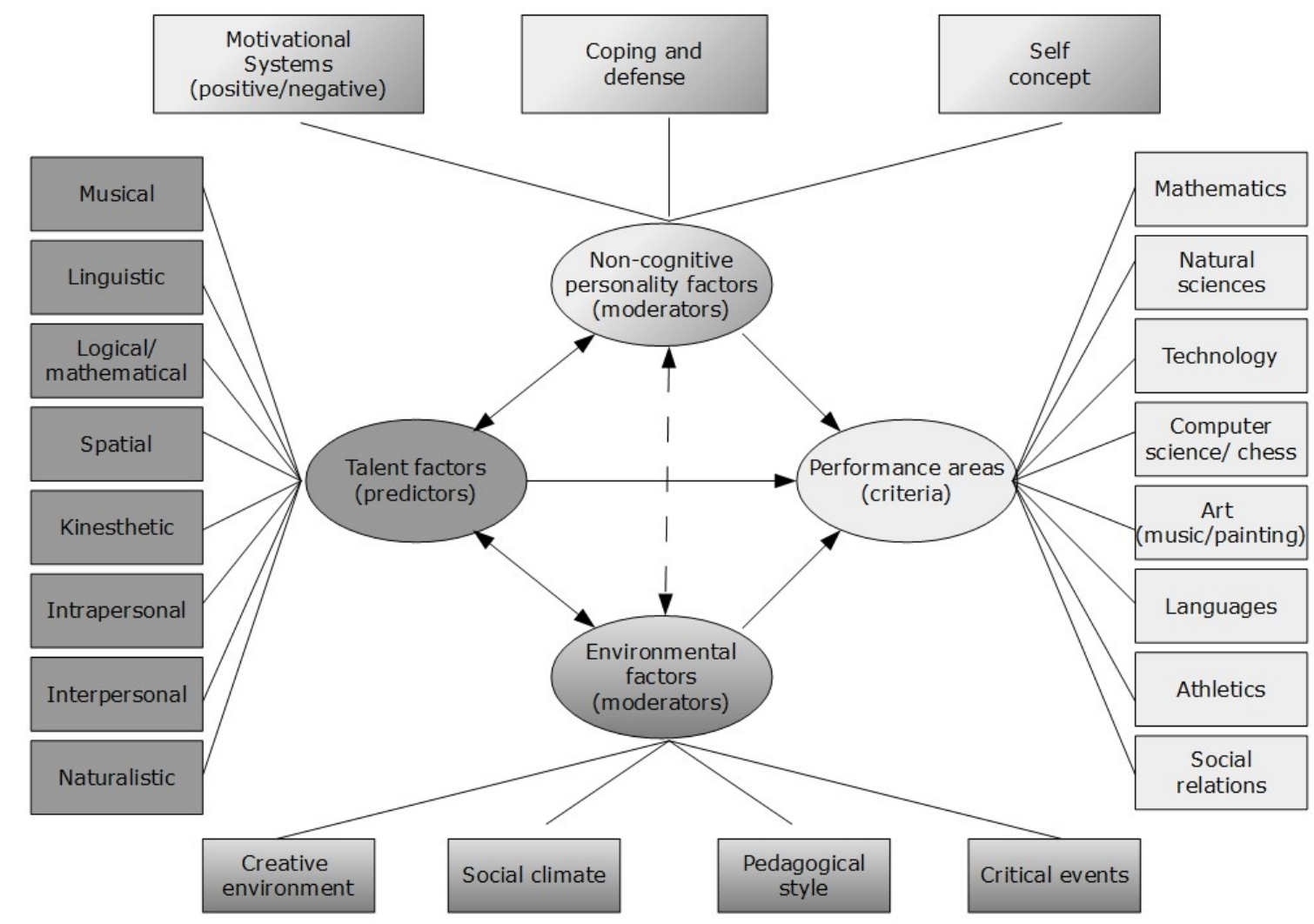

Figure 1: The Universal Model of Giftedness (UMG)

Multiple intelligences theory has been used within organizational sciences and applied to the workplace (Gale, 2013; Green et al., 2005; Hoffman \& Frost, 2006; Lane, 2009; Martin, 2003; Noruzi \& Rahimi, 2010; Vincent et al., 2002) and has found its way to counselling (Booth \& O’Brien, 2008; Pearson et al., 2015; Shearer \& Luzzo, 2009) and therapy (Pearson, 2011). The interpersonal and intrapersonal intelligence aligns to concepts such as emotional intelligence, or personal intelligence (Mayer et al., 2018; Park \& Park, 1997), and even mentalization (Fonagy et al., 2004) has overlap with these two intelligences. Most of the applications of Gardner's theory have been within the field of education. 
Creativeness (at the output side of the model) has to be allowed to express itself to be useful. This is not only something that the person does (non-cognitive personality factors), but which is influenced by the environment in which he exists. This means that in a work environment there are aspects that hamper or support the use of creativeness, there is a climate (or culture) of support for creativity. Because creativeness is an aspect of the definition of high giftedness (Renzulli, 1978, 2002), the creative environment was incorporated in the UMG (Jessurun et al., 2016, p. 120). These aspects are perceived by the individual workers, and these perceptions are of course mediated by the characteristics of these individuals. The characteristics of the work environment hampering or stimulating creative expression - the creativity supporting climate -, are described in Amabilee's Componential Model of Organizational Innovation, as 1) the organizational motivation to innovate, 2) resources provided or not, and 3) the management practices (Amabile, 2004). In the UMG the 'creative organization' is 'perceived' through the moderating variables such as defence/coping.

There are several ways to describe the different profiles of multiple intelligences. One of the ways is ordering the profiles from high to low. Gardner (1993, p. 36) describes laser and searchlight profiles. It is useful to look at the peaks and bottlenecks in the profile, and that people with for instance a peak on the linguistic intelligence, may be different from someone who has the musical intelligence as his highest ability. Another way of looking at a profile is to compare the highs and lows in it, with what the job demands for it, and what they might have in surplus or shortage.

\section{Chronic Relative Underperformance}

Motivation to do things, such as work, has both an intrinsic and an extrinsic component. The fact that there is an overlap between the Componential Model and high giftedness on creativity (Jessurun et al., submitted) is of significance in this regard. High gifted people are often performing under the level they might be capable of, even though they may be performing well enough according to what is expected from them as far as the job specifications go. A lot of problems gifted people have with their work are related to the fact that jobs 'cater to people with an average intelligence (van der Waal et al., 2013, p. 166)'. And this is probably not only true for high gifted people, but possible for all employees who may have capabilities or talents exceeding what their jobs asks for, or even not deemed of any use to their job. There is a (possible) job-person misfit (Jessurun et al., 2020). 


\section{Table 2}

Job Profile and individual profile in multiple intelligences

\begin{tabular}{lll}
\hline Intelligence & Job Profile & Example personal profile \\
\hline Interpersonal & 78 & 68 \\
Intrapersonal & 76 & 60 \\
Linguistic & 70 & 64 \\
Logical/Mathematical & 45 & 39 \\
Kinesthetic & 24 & 55 \\
Musical & 22 & 29 \\
Naturalistic & 20 & 58 \\
Visual/Spatial & 17 & 38 \\
\hline
\end{tabular}

Adapted from Jessurun \& Weggeman (2015, p. 30)

To illustrate this, we present you with an example of a job profile for mental health workers (see Table 2), for which the eight intelligences mentioned in Table 1 are used, and an example personal profile. Comparing these two profiles is not straightforward, even though both are using the same underlying concept. The questionnaires on which they are based, however, have different psychometric properties. Both are percentage scales, but 70 on the one profile does not exactly mean the same on the other (Jessurun et al., in review). However, what can be observed is that the mental health worker profile (MHWP) scores rather high on three intelligences: interpersonal, intrapersonal and linguistic (one would expect this, based on common sense - dealing with psychological problems involves knowledge of your own mind, dealing with those of others, mainly using language in working this through), in the middle on logical/mathematical, and low on visual/spatial, kinesthetic, musical, and naturalistic. In the personal profile, what stands out is especially the differences for the kinesthetic and the naturalistic scales. These might be talents, or capabilities that need to be expressed, that are not tapped into at the work environment, and which might lead to a subconscious dissatisfaction, which at some point might hamper effectiveness of the employee. Thus, this situation - when it lasts -, may become problematic, has been called Chronic Relative Underperformance, and may lead to boredom, and at a certain point even to boreout (Jessurun et al., 2020).

Using the MHWP and comparing this to individual profiles may give some insight in whether a person has capabilities beyond what is needed for his or her job, it cannot establish whether the person in question is in the chronic relative underperformance state (CRU). However, 
we expect that as the discrepancy is greater, there is more risk for chronic relative underperformance. We therefore expect, that when this risk gets higher, employees perceive the organization differently, which leads to the next presumption:

How individuals perceive the organizational climate on support for creativeness is related to how much of their capabilities are left unused; presumably the more capabilities are left unused the more negative the individual will regard the climate on support for creativeness.

\section{Methodology}

This research analysis data in order to explore whether the expectations we have regarding that the different intelligences are related to how employees see their organisations, and especially that in those cases where strengths they have are not used within their work are related to negative evaluations of their work environment, have any merit.

\section{Operationalization: Multiple Intelligences}

For the assessment of the multiple intelligences profiles, we use the MIDAS ${ }^{\text {TM }}$ (Shearer, 1996). This is a 119 items self-report questionnaire with Likert type scales, ranging from 0 to 4 , and an 'I don't know' category. The scales are computed as percentage scales and there are no norms applied. During the development of the scales the answering categories were adjusted, so that the average score over large samples for the scales would be around $50 \%$. This means that for each item, the wordings of the answering categories may differ. The MIDAS ${ }^{\mathrm{TM}}$ has been translated into several languages (e.g. Dutch, Spanish, Chinese, Farsi, Turkish), and has been researched on reliability and validity (Ostvar et al., 2012; Saban et al., 2012; Shearer, 1996).

The multiple intelligences are the main scales that the MIDAS ${ }^{\text {TM }}$ assesses. Using factor analysis different subscales have been described (Shearer, 1996). It is described, that a person can have a result of around $50 \%$ on a main scale, and have highly fluctuating results in the subscales comprising that main scale. For instance, the main scale Musical consists of the subscales musical appreciation, playing an instrument, vocal, and composing. It may be the case that someone has never played an instrument or composed music, but sings a lot and listens to music all the time. Therefore, it is not only interesting to see if the main scales show any relationship with the perception of the creative climate, but to also go down one level deeper. For a full list of the main scales and subscales of the MIDAS ${ }^{\mathrm{TM}}$, see appendix A. 
As well as subscales, the MIDAS ${ }^{\mathrm{TM}}$ assesses three 'intellectual styles', the way in which the person tends to solve problems (see table 2). Especially the innovative intellectual style is of interest, since it reflects a tendency to be creative. So a supplementary, we would expect that individuals who are predominant in this intellectual style, have a different perception of the creative support within the organization.

\section{Table 2}

Description of the MIDAS ${ }^{\mathrm{TM}}$ intellectual styles

\begin{tabular}{ll}
\hline Style & Description \\
\hline Leadership & $\begin{array}{l}\text { To use language effectively to organize and solve interpersonal problems \& } \\
\text { goals. }\end{array}$ \\
General logic & $\begin{array}{l}\text { To deal with problems in an intuitive, rapid and perhaps unexpectedly accurate } \\
\text { manner... to bring together a wide amount of information and to make it part of a } \\
\text { general and effective plan of action. }\end{array}$ \\
& $\begin{array}{l}\text { To work in artistic, divergent and imaginative ways. To improvise and create } \\
\text { unique answers, arguments or solutions. }\end{array}$ \\
\hline
\end{tabular}

Adapted from Shearer (1996)

\section{Operationalization: Risk for Chronic Relative Underperformance}

To compute the Risk for Chronic Relative Underperformance (rCRU) the method described by Jessurun et al. (in review) is used. To apply this method the data obtained by the MIDASTM, are compared with the mental health care job profile in multiple intelligences (MHWP - mental health worker profile), provided by Jessurun \& Weggeman (2015). The method computes a Mahalanobis distance (Mahalanobis, 1936) for the MIDASTM-scales higher than the profile to be compared against (plus), and for those lower than the profile expects (min). The mahalanobis-distance takes the correlations between the multiple intelligences into account, in determining the distance between them. Individuals with a higher mean distance on the plus-scales are considered to be more at risk of Chronic Relative Underperformance. This article is the first one using this index, and therefore it is of relevance to look more closely at how it, and the components of which it is computed, behave. In relation to how this research question has been worded (higher rCRU leads to negative effects), it makes more sense to look at only the plus scales, because that gives the index on the abilities which are left underused.

The thought on Chronic Relative Underperformance is, that when there are abilities or skills that are not asked for in the job profile, that this poses a greater risk for outcomes. The KEYS ${ }$ variables are all constructed in such a way, that higher means a positive influence. Another way to operationalize rCRU is to divide the subjects in two groups, a) those who have one of the essential 
MI's as their high peak intelligence (intrapersonal, interpersonal and linguistic), and b) those with the peak intelligence in one of the remaining MI's, the last group being those at risk for CRU. For all of the KEYS ${ }^{\circledR}$ variables, the expectation is that this last group will score lower than the first group.

\section{Operationalization: Assessment of the organization climate on creativity}

The KEYS ${ }^{\circledR}$ to Creativity and Innovation is a tool developed by the group of Amabile to identify the factors that support or inhibit innovation and creativity in an organization (Amabile, 1995; Amabile et al., 1996). It is a Likert-type questionnaire, in which employees rate their team, and their total organization on several aspects, leading to measurements on:

- management practices that impact innovation, the organizational stance on creativity, and resources, and

- a quantification on how productivity and creativity are perceived in an organization.

\section{Table 3}

Variables obtained with the KEYS® questionnaire

\begin{tabular}{|c|c|c|c|}
\hline $\begin{array}{l}\text { Management } \\
\text { Practices }\end{array}$ & $\begin{array}{c}\text { Organizational } \\
\text { Motivation }\end{array}$ & Resources & Outcomes \\
\hline $\begin{array}{ll}\text { - } & \text { Freedom } \\
\text { - } & \text { Challenging } \\
& \text { work } \\
\text { - } & \text { Managerial } \\
& \text { encouragement } \\
\text { - } & \text { Work group } \\
& \text { supports }\end{array}$ & $\begin{array}{ll}- & \begin{array}{l}\text { Organization } \\
\text { encouragement }\end{array} \\
\text { - } & \text { Lack of } \\
& \text { organizational } \\
\text { impediments }\end{array}$ & $\begin{array}{ll}\text { - } & \text { Sufficient } \\
\text { resources } \\
\text { - } & \text { Realistic } \\
\text { workload } \\
\text { pressures }\end{array}$ & $\begin{array}{ll}\text { - } & \text { Creativity } \\
\text { - } & \text { Productivity }\end{array}$ \\
\hline
\end{tabular}

Descriptions of what these variables mean, will be given below, where the statistical results are being presented.

\section{Data collection}

To explore our suppositions, we collected data from the employees of a large mental health organization in the Netherlands. On the intranet announcements had been made as to the global purpose of the project - researching the effects of underusing the talents of employees -, and it was made abundantly clear that participation was entirely voluntary. To include the data from a subject into the sample, he/she should have completed two online questionnaires 1) the MIDAS ${ }^{\text {TM }}$ (Shearer, 1996), and 2) the KEYS ${ }^{\circledR}$ (Amabile, 1995), Both questionnaires were presented simultaneously, so 
results could not have been influenced by the passing of time or interventions made on basis of the questionnaire results. Each participant completing the MIDAS ${ }^{\mathrm{TM}}$ automatically received a report on his multiple intelligences profile, and offered the possibility to follow a workshop on how to interpret the profile and how to use this for personal development. These were given after the closing time of the data collection.

From the 951 employees approached, 241 completed the MIDAS ${ }^{\mathrm{TM}}$ and 351 completed the KEYS®. Of these 189 could be matched; the rest did not complete the MIDAS ${ }^{\mathrm{TM}}$ or the KEYS®. For exploring our expectations regarding Risk of Chronic Relative Underperformance we needed the included persons to have a mental health function; after removing all non mental health care worker functions, a sample of 147 observations remained. Of the 189 matched records, 16 could be labelled as having a predominant innovative intellectual style.

\section{Model and statistical hypothesis}

(1) For the expectation, about different MI profiles and different perceptions of the work environment, we use a correlational design. Because of the way that the data were obtained, it will not be possible to make any causal statements. The theory so far does not generate hypotheses regarding the direction of the relations between multiple intelligences and the perception of the work environment. The nature of the research question is exploratory, and therefore a two-sided test of correlation is chosen with an $\alpha$ of $5 \%$.

(2) Computing correlations between the variables is one way to test whether different profiles fluctuate with different levels of appreciation of the work environment. In this way each intelligence is assessed on its own, and not in relation to 'a profile with weaknesses and strengths'. So, do people with intelligence $x$ as the highest differ from those with one of the other intelligences as the highest. For our purposes this will be the operationalization of the 'laser-point' in the profile, even though this does not correspondent for all profiles with the definition of a laser profile as meant by Gardner (2002). To test the differences between 'high point/laser point intelligence' and for the 'bottleneck intelligence' the data are categorized in two times eight groups, according to the highest scoring and the lowest scoring intelligence, and we test whether the means of the groups differ from each other using the $t$-test for independent samples, with an $\alpha$ of $5 \%$.

(3) For the research question on rCRU we expect that when the risk gets higher, that the work environment is evaluated as more poorly. The statistical hypotheses, for all relations in the correlational matrix between $\mathrm{rCRU}$ and the KEYS ${ }^{\circledR}$ variables, is a one-sided test, also at an $\alpha$ of $5 \%$, where we expect the correlations to be negative. 
(4) The differences between the subjects having their highest intelligence in the 'used' versus in the 'unused' group on the KEYS ${ }^{\circ}$ variables will be tested one-sided with the $t$ test for independent samples, at an $\alpha$ of $5 \%$, where we assume that the scores are lower for the subjects having their highest intelligence in the 'unused' intelligences.

(5) For the supplementary presumption, that subjects with a predominant innovative intellectual style have a different perception of the organization, we divide the subsample of matched persons, into two groups, those who have the innovative intellectual style as the highest of the three intellectual styles and those who have one of the other two as highest. For these two groups the means will be computed for the KEYS ${ }^{\circledR}$ variables, and the differences between will be tested two-sided with the t-test for independent samples with an $\alpha$ of $5 \%$.

\section{Results}

\section{Multiple Intelligences and perception of environment}

The Pearson correlation matrix between the MIDAS ${ }^{\mathrm{TM}}$ variables and the KEYS ${ }^{\circledR}$ is to be found in Appendix A - Table 1. Of the 390 correlations in the matrix 85 are significant on at least the 5\% level. All are to be categorized as weak (Akoglu, 2018). Below we will describe the variables which have a significant correlation, from the perspective of the work environment variables. The descriptions of the variables from the KEYS ${ }^{\circledR}$ are taken from the KEYS® to Creativity and Innovation User's Guide (Center for Creative Leadership, 2010). MIDAS variable descriptions are from Shearer (1996), and also given in Appendix A.

Freedom: None of the intelligences or intellectual styles show significant relations with the sense of control over one's work; deciding what or how to do your job. The only MIDAS ${ }^{\mathrm{TM}}$ subscale that has a (weak) correlation is intrapersonal: personal knowledge, which is the awareness of one's own ideas, and abilities, and able to achieve personal goals.

Challenging work refers to the sense of having challenging tasks and working on important projects. There are five intelligences that have a weak positive relation to this. This means that when someone scores higher on intrapersonal, interpersonal, linguistic, visual spatial or logical mathemetical intelligence, one tends to experience the work as somewhat more challenging. The two emotional intelligences have the highest correlations. There are 8 subscales on which there is a correlation. The highest of these is the personal knowledge subscale. 
Out of the 40 main- and subscales of the MIDAS ${ }^{\text {TM }} 20$ of them correlate significantly with this variable. All three intellectual style scales load positively on this scale; the pragmatical style the highest. The innovative style lags behind.

Managerial encouragement, the sense that the boss gives a good role example, sets appropriate goals, supports the workgroup, values individual contributions, and show confidence in the workgroup, does not vary with any of the intelligences or intellectual styles, and only correlates significantly with the subscale personal knowledge, indicating that people who are more capable of setting and evaluating their own goals, feel somewhat more supported by their direct management.

Almost the same is true for workgroup supports, the sense that the individual is working in a diversely skilled group in which people communicate well, are open to new ideas, constructively challenge each other's work, trust and help each other, and feel committed to the work. Only one of the subscales correlates significantly, in this case spatial awareness, which is about moving objects through space easily (such as driving a car); this does not have an intuitive explanation.

For organizational encouragement, the perception of the organizational culture that encourages creativity through the fair and constructive judgment of ideas, reward and recognition for creative work, mechanisms for developing new ideas, an active flow of ideas, and a shared vision, we see that there are no significant relations, even though all are negative, apart from visualspatial intelligence.

Lack of organizational impediments, which means that the culture in the organization is perceived as not impeding creativity, because of internal political problems, harsh criticism of new ideas, destructive internal competition, avoidance of risk, and overemphasis on the status quo, comes out 17 times of 40 as significant, and has negative correlations with the logicalmathematical, intrapersonal, visual-spatial, and kinesthetic intelligences, as well as with all intellectual styles. This indicates that the higher these are, the more the persons do feel impeded by the mentioned cultural aspects..

Sufficient resources, the sense that there is access to appropriate resources, including funds, materials, facilities, and information, did correlate, but very weak with the naturalistic intelligence, and not with any other intelligences or the intellectual styles. It correlates with two of the subscales of the MIDAS ${ }^{\mathrm{TM}}$, positively with personal knowledge on the one hand, and negatively with science (knowledge of energy systems, physics, weather systems),

The sense of a realistic workload, that is an absence of extreme time pressures, unrealistic expectations for productivity, and distractions from creative work, shows negative weak correlations with the naturalistic, logical-mathematical, visual-spatial, linguistic, and intrapersonal 
intelligences, as well as with leadership and innovative as intellectual styles. So the higher these are, the more the persons tend to experience the workload as unrealistic. Of the 40 scales and subscales there are 20 correlations, all of these negative.

The KEYS ${ }^{\circledR}$ has two outcome measurements, how the subjects assess their organization as creative, and productive. Off all scales- and subscales of the MIDAS ${ }^{\mathrm{TM}} 23$ of them correlate significantly with creativity. The top five of these are personal knowledge (intrapersonal) at 0.314 , the pragmatical intellectual style at 0.304, and the Intrapersonal intelligence at 0.278 , the innovative intellectual style at 0.271, and the Interpersonal intelligence at 0.259. All of the correlations are positive. For productivity there are 5 correlations significant at an $\alpha$ of $5 \%$, and these are personal knowledge at 0.233 , working with people (interpersonal) at 0.156 , the pragmatical intellectual style at 0.155 , the Intrapersonal intelligence at 0.151 , and lastly the vocal subscale of the Musical intelligence at 0.144; this last one suggesting that if you are able to sing well, you tend to see the productivity of the organization as somewhat better (or the other way around, because of the non-causality of the research design). Of all the 40 correlations on the productivity variable, 11 are negative, none of these get to the level of significance we used.

\section{Innovative Intellectual Style and the perception of the environment}

Only 16 profiles were found to have a predominant innovative intellectual style. None of the comparisons between this intellectual style and the KEYS ${ }^{\circledR}$ variables had a significant two-tailed result, using the t-test for independent samples. Also see Appendix B - Table 2, for means and standard deviations.

\section{Highpoint and lowpoint MI-profiles and perception of environment}

Comparing the group of individuals with one of the multiple intelligences as the highest with the rest of the group on the variables of the KEYS $\AA$, we get some statistically significant results, as shown in table 4 . The comparison on KEYS ${ }^{\circledR}$ variables between the group with one of the intelligences as the lowest with the rest is to be found in Table 5. The full tables are given in Appendix B, Tables 4 and 5. The frequencies of high- and low-point intelligences (Appendix B Table 3) are not distributed evenly across the intelligences for the high point profiles $\left(\chi^{2}=117,299\right.$, $\mathrm{df}=0, \mathrm{p}<, 000)$, nor for low point profiles $\left(\chi^{2}=159,652, \mathrm{df}=0, \mathrm{p}<, 000\right)$. 


\section{Table 4}

Means on the KEYS ${ }^{\circledR}$ variables, comparing the group with highest intelligence, versus the rest; only the significant results given

\begin{tabular}{llccc}
\hline HIGHPOINT & KEYS® & highest & Rest & $p$ \\
\hline LOGICAL-MATHEMATICAL & creativity & 2,9583 & 2,5849 & 0,0296 \\
LINGUISTIC & challenging work & 2,9554 & 2,7517 & 0,0311 \\
INTERPERSONAL & workgroup support & 3,1146 & 2,9524 & 0,0152 \\
INTRAPERSONAL & creativity & 2,2933 & 2,6098 & 0,0234 \\
NATURALISTIC & creativity & 2,3756 & 2,6311 & 0,0454 \\
\hline
\end{tabular}

Tested with the Welch Two Sample T test at an $\alpha$ of $5 \%$.

The output variable creativity, which relates to the individual assessing the organization as supporting creativeness, comes up statistically significant three times. Logical-mathematical high point profiles do assess the environment as more creative. Linguistic people find the environment offering challenging work (meant in the positive way). Interpersonal high scorers do experience the group in which they are working as more supportive.

For the intrapersonal and naturalistic high profiles the direction is negative. Intrapersonal people experience less support for creativeness. Naturalistic people the environment less supportive for creativeness.

\section{Table 5}

Means on the KEYS® variables, comparing group with lowest intelligence versus the rest; only the significant results given

\begin{tabular}{llrrr}
\hline LOWPOINT & KEYS® & lowest & rest & p \\
\hline MUSICAL & productivity & 2,6705 & 2,8335 & 0,0168 \\
KINESTHETIC & productivity & 2,9346 & 2,7433 & 0,0365 \\
VISUAL-SPATIAL & organization encouragement & 2,1704 & 2,4069 & 0,0295 \\
& creativity & 2,2278 & 2,6318 & 0,0107 \\
LINGUISTIC & productivity & 3,3722 & 2,7499 & 0,0085 \\
INTRAPERSONAL & challenging work & 1,5000 & 2,8059 & 0,0257 \\
NATURALISTIC & realistic workload pressure & 2,8571 & 2,6419 & 0,0441
\end{tabular}

Tested with the Welch Two Sample T test at an $\alpha$ of 5\%.

What is different here, is that the other outcome measurement of the KEYS ${ }^{\circledR}$ (productivity) shows up in these results, as well as several variables that were significant above, To summarize:

- the group with musical intelligence as their lowest in the profile, do experience the organization as less productive; 
- the non-kinesthetic group finds the organization more productive;

- the same holds for the group who are least linguistically inclined; less talk, more productive;

- the group of people who are not really using images to solve problems, feel less encouraged by the organization, and assess the organization as less supportive of creativity, than all the others with another intelligence as the lowest in their profile;

- those people with the least intrapersonal intelligence (less aware of their needs, less able to set their own goals), assess their jobs as having less challenging work; and

- people with the naturalistic intelligence as the lowest, seem to be inclined to think that the workpressure is realistic.

\section{Risk for Chronic Relative Underperformance and perception of environment}

The correlations between $\mathrm{rCRU}$ and the KEYS ${ }$ variables are given in Table 6 . There were several records in which either the number of plus- or min-scales was 0 ; in these cases a mean value could not be computed, so we assigned the difference a value of 4 when all scales were plus, and -3 when all scales were min. These values were just outside the range of those that could be computed.

\section{Table 6}

Correlations between $r C R U$ and the KEYS® variables

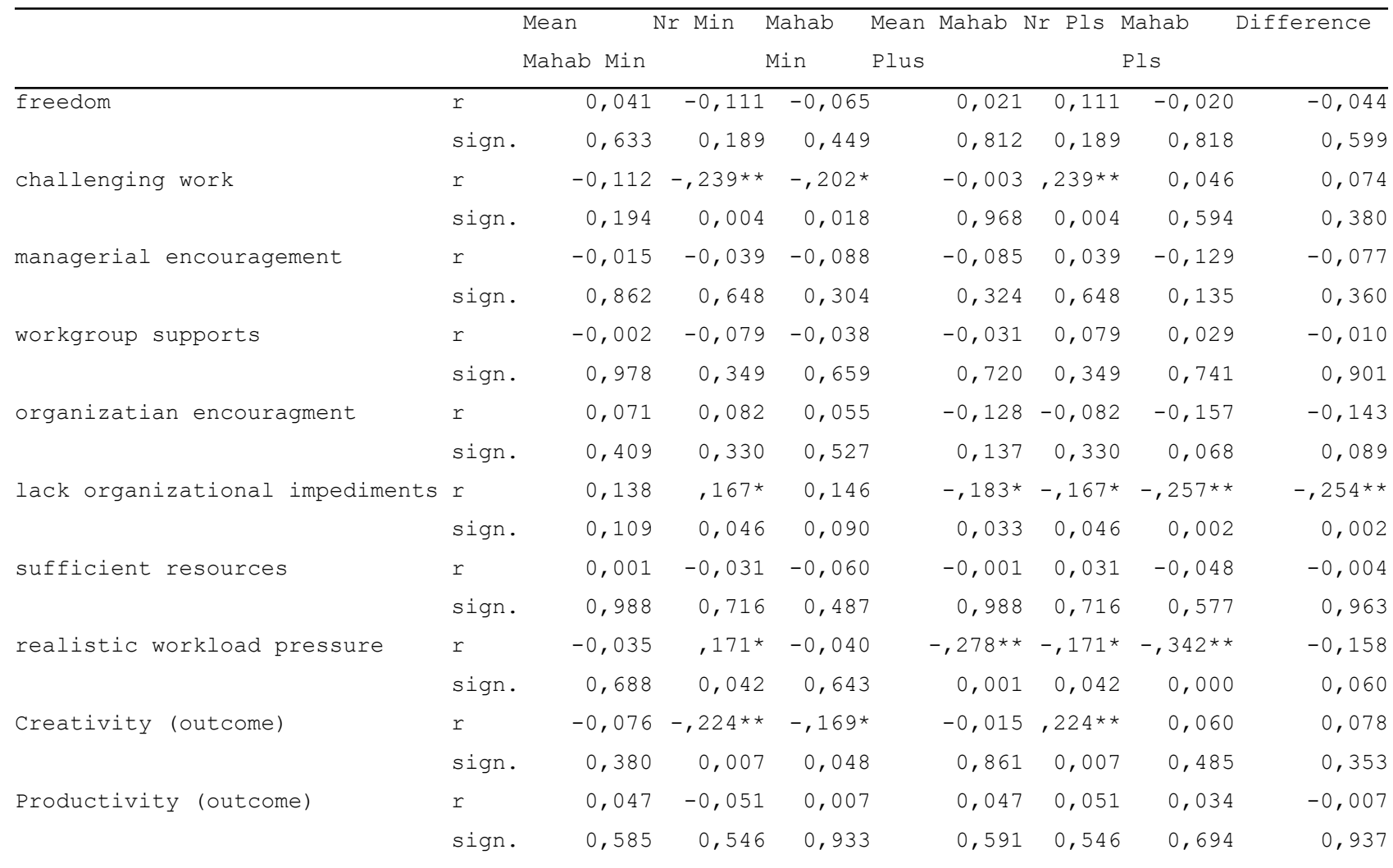




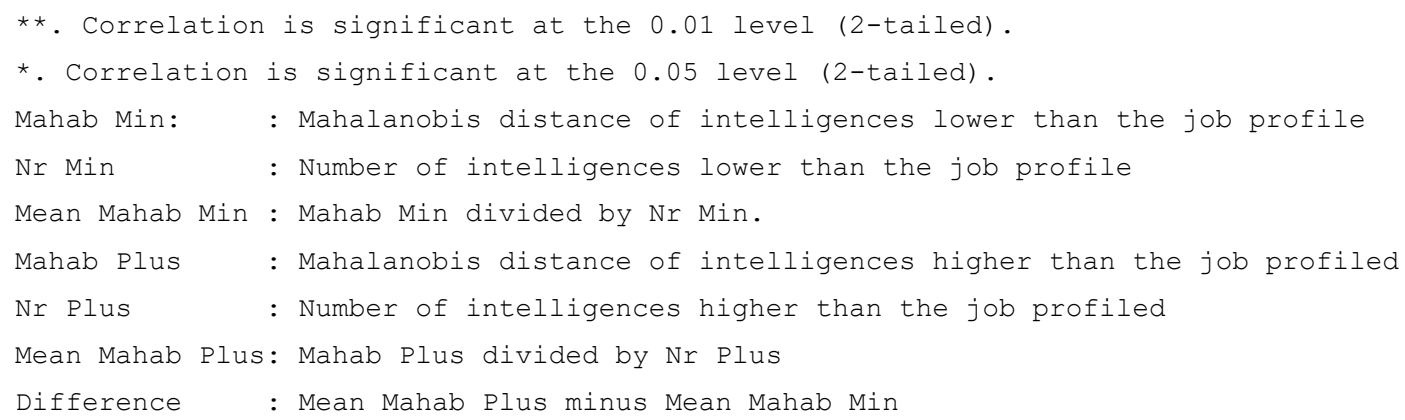

A significant correlation for the rCRU index as proposed by Jessurun et al. (submitted), the difference between the mean mahalanobis-distance of plus and min scales, is for lack of organizational impediments. This is a weak, negative correlation. When we observe the correlations for only those scales on which the individual abilities are underused (Mean Mahab Plus), we see the same negative correlation for the lack of organizational impediments, and a (tending to moderate but still weak) negative correlation for realistic workload pressure gains a $\mathrm{p}<0.01$.

There are some other correlations, between the number of plus- or min-scales and the KEYS ${ }^{\circledR}$ variables. The number of scales comprising the distance is significantly, though weakly, related to:

- challenging work: work is found less challenging (the sense of working on challenging projects and things of interest) when the number of scales which are below the job-profile increases;

- lack of organizational impediments: when there are more scales below specs for the job, the person feels less hindered by organizational politics and so on. The higher the number of plus scales, the individual feels a bit more hindered. This would be in the expected direction;

- realistic workload pressure: higher number of min-scales has a low positive correlation with work pressure, so these individuals find that the workload is somewhat more realistic, less stressful in time mangement. The higher the number of plus-scales, the more the person feels that the workload is unrealistic, time-pressure higher, and hindering creative work. Again this is in the expected direction;

- creativity: the higher the number of plus-scales, the more the person experiences the organization as creative.

The rCRU index uses the Mahalanobis-distance, taking into account the correlations between the MI scales to compute the distance. As the rCRU is a significant reduction of the data underlying its value (eight intelligences), it might be possible the effect that using the Mahalanobis- 
distance has, is that the variance is flattened even more. To have some idea about this, we also computed the Euclidean distances (see Appendix B - Table 6). There are no relevant correlations using the mean Euclidean distances.

Looking at the differences between the group of people having their high-point intelligence in one of the three needed intelligences for the job profile, compared with those with having their high-point intelligence in one of the other five, which is the second way to operationalize rCRU, we see that, at an $\alpha$ of $5 \%$, the group at risk assesses work-environment as significantly lower, except for managerial encouragement. Also, for the outcome variables they assess the productivity of the organization as lower, though there is no statistical difference in how creative they think the output of organization is (see Table 7).

\section{Table 7}

Comparison of the group with one of the essential MI's in their profile as highest (essentials) with those with one of the not needed MI's as highest in their profile for the KEYS® variables

\begin{tabular}{lrrr}
\hline KEYS@ ${ }^{-}$ & Essentials & Not needed & n \\
\hline freedom & 2,6282 & 2,5123 & 0,0430 \\
challenging work & 2,8555 & 2,7184 & 0,0396 \\
managerial encouragement & 2,8387 & 2,7163 & 0,0660 \\
workgroup supports & 3,0739 & 2,9360 & 0,0163 \\
organization encouragement & 2,4422 & 2,3239 & 0,0288 \\
lack of organizational impediments & 2,8366 & 2,7115 & 0,0106 \\
sufficient resources & 2,8044 & 2,6577 & 0,0149 \\
workpressure & 2,7606 & 2,5932 & 0,0167 \\
creativity & 2,6158 & 2,5667 & 0,2743 \\
productivity & 2,8280 & 2,7012 & 0,0235 \\
\hline
\end{tabular}

Welch Two Sample t-test, one sided

\section{Conclusions}

(1) The results show that there is evidence that different multiple intelligences do have a relation with the perception of the support for the creative environment. Especially the intrapersonal intelligence correlates with the highest number of the KEYS ${ }^{\circledR}$ variables, as well as the personal knowledge subscale of this intelligence. This means that there is support for our expectation that there is a relation between MI and perception of the supportiveness of the organization on creativity.

(2) Laser-profiles and bottleneck-profiles do show a different result on the perception of the organization. The results are mainly on the challenging variable and the output variable creativity, for the laser-profiles; on challenging, and the output variable productivity for the bottleneckprofiles. 
(3) When using the profile comparison method proposed by Jessurun et al. (in review), there is some evidence for rCRU, being related negatively to the positive evaluation of workplace variables. People high on rCRU do seem to see the organization as having a culture in which politics plays a role. Also they find workpressure to be higher and more unrealistic. On the other hand they see the organization as having a somewhat higher creativity output. The hypotheses regarding rCRU therefore get support.

(4) All KEYS® variables, except the outcome variable productivity, are significantly lower for the group of persons with their peak intelligence falling outside of the job-profile. The expectation that 'unused' intelligences are related to a negative evaluation of the work environment regarding creativity, is therefore supported.

(5) At this point, there is no evidence for the tenacity of our expectation about specifics between this intellectual style (especially on the innovative intellectual style) and how the individual assesses characteristics of his work environment.

\section{Discussion}

\section{The intelligence profile matters}

Correlating the MIDAS ${ }^{\mathrm{TM}}$ variables with the KEYS ${ }^{\circledR}$ variables led to 390 correlations of which 85 are significant on at least the 5\% level (Appendix B - Table 1). This means that at the worst some 19 of the correlations could be assigned to pure chance. It may be concluded that indeed different profiles of multiple intelligences relate to different perceptions of the organization. The importance of the correlations present, are in our view supported by the results of the differences between high-point groups, low-point groups and especially the rCRU-group differences.

The MIDASTM and the KEYS ${ }^{\mathrm{T}}$ are both instruments that ask the subjects to report on how they assess an 'object', though the direction of the assessment is opposite. The MIDAS ${ }^{\text {TM }}$ is directed inwards, the person is reflecting upon him- or herself, and the KEYS ${ }$ is directed outwards, asking the person to reflect upon the organization in which he or she is working. Even though it is realistic to assume that personality and capabilities of the person has influence on how he or she assesses a situation (otherwise the whole point of this research would be moot), high correlations between intelligence and the different circumstances measured by the KEYS ${ }^{\circledR}$ would be unexpected. For instance, a correlation of about -0.8 between visual-spatial intelligence and the sense of a realistic workload, would be quite disturbing if this had not been picked up before in earlier research and translated to management practices, where people that think in images were 
supported to experience less workload. Therefore, we are of the opinion that the correlations that present themselves here may be weak, but interesting enough.

There has been much criticism on the theory of multiple intelligences, especially within the IQ domain, which reveals itself in the discussion of $g$ (general intelligence). There has been no resolution of these issues. Jessurun, Shearer \& Weggeman (2016) conclude that the debate takes place on two different levels of aggregation and that both approaches have different merits and understand different phenomena. The existence of $g$ has not been questioned by multiple intelligence theory at all, it mainly asks what $g$ explains (Gardner, 1999, p. 7). With the advance of neuropsychological research techniques, it becomes more and more clear that there is evidence for the concept of multiple intelligences (Shearer, 2020; Shearer \& Karanian, 2017). The present research does suggest, is that using the concept of multiple intelligences leads to some meaningful results, which can be of practical use as well, mainly in human resource managing, as described below.

Even though it might be obvious, this research gives evidence that intrapersonal intelligence, the very private intelligence, 'knowing thyself', having access to your feelings, to discriminate between them, label them and using them to guide ones behaviour, and having a viable and effective model of him- or herself (see Gardner, 1993, p. 17), is of importance in the work environment. The results suggest, that a person who is good at this intelligence, sees his work as more challenging, the organization having more creative output and being more productive, even though he feels a little more organizational impediments, and suffers somewhat more from unrealistic workpressure. There are indications, from the subscale personal knowledge, that he experiences more freedom, support from management and enough resources to do his work. People with this intelligence as the lowest experience less freedom of choice in doing their job, and find there work non-challenging. Of course we need to be prudent about the results; as for now there is no solid base of evidence to suggest that personal intelligences, or emotional intelligences, in the workplace matter much (Zeidner et al., 2004).

\section{A specific sample of subjects}

We have to be reserved about the results, first because of the fairly low (even though consistent) correlations, but also, because of the characteristics of the subjects. Mental health care workers are not 'average'. They are highly educated, and highly skilled in dealing with difficult feelings, concealed motives and desires, knowledgeable in psychic disturbances and so on. This might have an influence on how they assess themselves and the environment, and this might be 
different from other groups. So, it is quite unclear whether the results can be generalized to employees in other domains.

The second circumstance which we need to take into account, especially when evaluating the results from the rCRU, is that in this research we had only one job profile to compare against. We cannot say whether subjects with another job profile and their own personal MI-profiles, when assessing their organization on the $\mathrm{KEYS}{ }^{\circledR}$ will give similar results. Needless to say is, that more research is necessary to answer these questions.

\section{Selection of employees}

The conclusion is, that it is meaningful for organizations to have some idea about were the talents of their employees lie, and that especially some aspects of the assessment of the organizational environment vary with the capabilities and skills (intelligences) of their employees.

What we do not propose is that the results from this research could in any way be sufficient for selection purposes. The MIDASTM is too crude an instrument for this, and as argued before, the relations are there, but weak. Administering the questionnaire and then concluding that because of being higher at risk for CRU, based upon the high-point scale in one of the not necessary intelligences, the person should not be hired, would be unethical, and go beyond what this research meant to achieve.

What the model of multiple intelligences might be used for is to get a snapshot of the organization, if the employees are willing to do the assessment, and then use the results to prevent the things perceived as negative, such as the possible assessment of the work pressure, or how the organization makes it more difficult to see the organization as creative, or productive, by impediments. To enhance the possibilities to be creative in their work, is important for the wellbeing of the employees (Helzer \& Kim, 2019). Creativeness is a habit, that can be and often is suppressed (Sternberg, 2012). Organizations often ask for creative thinking people, as long as when they are hired they do not act creatively, thus disturbing standards and protocol, and the way we do things (Persson, 2017).

\section{Reducing the chance of $C R U$}

How individuals experience work pressure, and how much the organizations is hindering creativeness, correlates negatively with calculated rCRU. Comparing subjects with not-used skills and abilities to the ones needed in the job profile, also shows a negative effect for these two KEYS ${ }^{\circledR}$ input variables. What this might suggest is that, since about half of the subjects are in the 
rCRU-group, that it is useful to know about this, and to devise strategies that might prevent negative effects. For instance, it may be useful to address the workload and the 'politicals' of the organization during the yearly assessment of the employee, especially when the signals are there that they might have a CRU-profile. This might help in reducing burnout, boreout, or job-hopping.

One of the steps in the personal validation of a MIDASTM-profile, is the "validation interview', one element is exploring the activities a person likes to do and reflect upon these specifically, trying to align these with possibilities in their work. When this interview was with the management team of the organization in which this research was done, it surfaced that one of the financial managers used to be a carpenter and had a keen eye for interior design. In other words, he possessed a whole range of skills that were not used in his job. What came from this, was the agreement, that if another building would be opened, he would be consulted on the interior design. A boost of energy within the whole group of managers resulted from this. The lesson learned from this example, and corroborated by the results from this research, is that it is important to know your employees beyond the skills needed. Taking the full complement of skills and abilities into account, the 'whole person', in stead of only those needed for the job, and planning the employees career together with him, might lower the risk for dropout significantly.

The results of this research shows that talents or skills and abilities beyond those needed in the function has its influence on how the organization is seen by the employees, also in its productivity and creativity. It suggests that Taylorism is like the worm Ourouboros, biting its own tail. The nature of work is changing, and it is needed to attend more to individual differences in knowledge, skills and motivation (Ackerman \& Kanfer, 2020). Further research on multiple intelligences, different profiles within and without job requirements, risk of chronic relative underporformance, and what this means for employees and the organizations they work in, or how it influences there performance, seems merited. 


\section{References}

Ackerman, P. L., \& Kanfer, R. (2020). Work in the 21st century: New directions for aging and adult development. American Psychologist, 75(4), 486-498. https://doi.org/10.1037/amp0000615

Akoglu, H. (2018). User's guide to correlation coefficients. Turkish Journal of Emergency Medicine, 18(3), 91-93. https://doi.org/10.1016/j.tjem.2018.08.001

Amabile, T. M. (1995). KEYS: Assessing the climate for creativity. Center for Creative Leadership.

Amabile, T. M. (2004). A Model of Creativity and Innovation in Organizations. In B. M. Staw \& L. L. Cummings (Eds.), Research in organizational behavior (Vol. 10, pp. 123-167). JAI Press.

Amabile, T. M. (2006). Creativity and innovation in organizations. Harvard Business School.

Amabile, T. M., Conti, R., Coon, H., Lazenby, J., \& Herron, M. (1996). Assessing the Work Environment for Creativity. Academy of Management Journal, 39(5), 1154-1184.

Booth, R., \& O’Brien, P. J. (2008). An Holistic Approach for Counsellors: Embracing Multiple Intelligences. International Journal for the Advancement of Counselling, 30(2), 79-92. https://doi.org/10.1007/s10447-008-9046-0

Center for Creative Leadership. (2010). KEYS® to Creativity and Innovaion User's Guide. Center for Creative Leadership.

Edwards, J. R., Caplan, R. D., \& Harrison, R. van. (1998). Person-Environment Fit Theory: Conceptual Foundations, Empirical Evidence, and Directions for Future Research. In C. L. Cooper, Theories of Organizational Stress. (pp. 28-67). Oxford University Press.

Edwards, J. R., \& Shipp, A. J. (2007). The Relationship Between Person-Environment Fit and Outcomes: An Integrative Theoretical Framework. In C. Ostroff \& T. A. Judge (Eds.), Perspectives on Organizational Fit (pp. 209-258.). Jossey-Bass.

Fonagy, P., Gergely, G., Jurist, E. J., \& Target, M. (2004). Affect regulation, mentalization, and the development of the self. Karnac Press.

Gale, L. Y. (2013). An examination of Gardner's multiple intelligences of leadership in organizations. Capella University.

Gardner, H. (1983). Frames of mind: The theory of multiple intelligences. Basic Books. 
Gardner, H. (1993). Multiple intelligences: New horizons. BasicBooks.

Gardner, H. (1999). Intelligence Reframed-Multiple Intelligences for the 21st Century. Basic Books.

Gardner, H. (2000). A Case Against Spiritual Intelligence. The International Journal for the Psychology of Religion, 10(1), 27-34. https://doi.org/10.1207/S15327582IJPR1001_3

Gardner, H. (2002). Multiple intelligences: The theory in practice. BasicBooks.

Green, A. L., Hill, A. Y., Friday, E., \& Friday, S. S. (2005). The use of multiple intelligences to enhance team productivity. Management Decision, 43(3), 349-359. https://doi.org/10.1108/00251740510589742

Heller, K. A. (2004). Identification of Gifted and Talented Students. Psychology Science, 46(3), $302-323$.

Heller, K. A., \& Hany, E. A. (1986). Identification, development, and achievement analysis of talented and gifted children in West Germany. In H. Heller Kurt A. \& J. F. Feldhusen (Eds.), Identifying and Nurturing the Gifted; An International Perspective. (pp. 67-82). Huber Publ.

Helzer, E. G., \& Kim, S. H. (2019). Creativity for Workplace Well-Being. Academy of Management Perspectives, 33(2), 134-147. https://doi.org/10.5465/amp.2016.0141

Hoffman, B. J., \& Frost, B. C. (2006). Multiple intelligences of transformational leaders: An empirical examination. International Journal of Manpower, 27(1), 37-51. https://doi.org/10.1108/01437720610652826

Jessurun, J. H., Anthonio, G. G., Gelper, S. E. C., \& Weggeman, M. C. D. P. (submitted). Building Bridges: On the Overlap Between the Component Model of Creativity and the Model of High Giftedness. SAGE Open.

Jessurun, J. H., Gelper, S. E. C., Weggeman, M. C. D. P., \& Anthonio, G. G. (in review). A PersonJob Fit Index Using Multiple Intelligences Profiles: Calculating Risk for Chronic Relative Underperformance. SAGE Open. 
Jessurun, J. H., Shearer, C. B., \& Weggeman, M. C. D. P. (2016). A Universal Model of Giftedness - an adaptation of the Munich Model. High Ability Studies, 27(2), 113-128. https://doi.org/10.1080/13598139.2015.1108184

Jessurun, J. H., \& Weggeman, M. C. D. P. (2015). Multiple intelligences job profile and job-person fit, MIDAS-JOB: Development and manual. TweeMC.

Jessurun, J. H., Weggeman, M. C. D. P., Anthonio, G. G., \& Gelper, S. E. C. (2020). Theoretical reflections on the underutilisation of employee talents in the workplace and the consequences. Sage Open, 10(3), 1-12. https://doi.org/10.1177/2158244020938703

Lane, I. F. (2009). Professional competencies in health sciences education: From multiple intelligences to the clinic floor. Advances in Health Sciences Education, 15(1), 129-146. https://doi.org/10.1007/s10459-009-9172-4

Mahalanobis, P. C. (1936). On the generalized distance in statistics. Proceedings of the National Institute of Sciences of India, 2(1), 49-55.

Martin, J. (2003). Multiple Intelligences and Business Diversity. Journal of Career Assessment, 11(2), 187-204. https://doi.org/10.1177/1069072703011002005

Mayer, J. D., Lortie, B., Panter, A. T., \& Caruso, D. R. (2018). Employees High in Personal Intelligence Differ From Their Colleagues in Workplace Perceptions and Behavior. Journal of Personality Assessment, 100(5), 539-550. https://doi.org/10.1080/00223891.2018.1455690

Mumford, M. D., \& Simonton, D. K. (1997). Creativity in the Workplace: People, Problems, and Structures. The Journal of Creative Behavior, 31(1), 1-6. https://doi.org/10.1002/j.21626057.1997.tb00776.x

Noruzi, M. R., \& Rahimi, G. R. (2010). Multiple Intelligences, A New Look to Organizational Effectiveness. Journal of Management Research, 2(2).

Ostvar, S., Shearer, C. B., \& Jafarabadi, M. A. (2012). Content Validity and Reliability of Multiple Intelligences Developmental Assessment Scales (MIDAS) Translated into Persian. Journal of English Language Pedagogy and Practice, 5(11), 116-134. 
Park, L. C., \& Park, T. J. (1997). Personal Intelligence. In M. McCallum \& W. E. Piper (Eds.), Psychological Mindedness: A Contemporary Understanding (pp. 133-167).

Pearson, M. (2011). Multiple intelligences and the therapeutic alliance: Incorporating multiple intelligence theory and practice into counselling. European Journal of Psychotherapy \& Counselling, 13(3), 263-278. https://doi.org/10.1080/13642537.2011.596725

Pearson, M., O’Brien, P., \& Bulsara, C. (2015). A Multiple Intelligences Approach to Counseling: Enhancing Alliances With a Focus on Strengths. Journal of Psychotherapy Integration. https://doi.org/10.1037/a0038881

Persson, R. S. (2017, July 2). The Few, The Proud and The Brave: The 15th International ICIE conference on Excellence, Innovation \& Creativity, Basic-Higher Education and Psychology, Lisbon. https://www.diva-portal.org/smash/get/diva2:1120929/FULLTEXT01.pdf

Renzulli, J. S. (1978). What Makes Giftedness? Reexamining a Definition. Phi Delta Kappan.

Renzulli, J. S. (2002). Emerging Conceptions of Giftedness: Building a Bridge to the New Century. Exceptionality, 10(2), 67-75. https://doi.org/10.1207/S15327035EX1002_2

Saban, A. I., Shearer, C. B., Kayiran, B. K., \& Isik, D. (2012). The validity and reliability study of Turkish version of the multiple intelligences developmental assessment scales [Data set]. In International Journal of Human Sciences: Vol. 9(2) (pp. 651-666). https://doi.org/10.1037/t05079-000

Shearer, C. B. (1996). The MIDAS: A professional manual. Greyden Press.

Shearer, C. B. (2020). A resting state functional connectivity analysis of human intelligence: Broad theoretical and practical implications for multiple intelligences theory. Psychology \& Neuroscience. https://doi.org/10.1037/pne0000200

Shearer, C. B., \& Karanian, J. M. (2017). The neuroscience of intelligence: Empirical support for the theory of multiple intelligences? Trends in Neuroscience and Education, 6, 211-223. https://doi.org/10.1016/j.tine.2017.02.002

Shearer, C. B., \& Luzzo, D. A. (2009). Exploring the Application of Multiple Intelligences Theory to Career Counseling. The Career Development Quarterly, 59(Sept), 3-13. 
Sternberg, R. J. (2012). The Assessment of Creativity: An Investment-Based Approach. Creativity Research Journal, 24(1), 3-12. https://doi.org/10.1080/10400419.2012.652925

van der Waal, I., Nauta, N., \& Lindhout, R. (2013). Labour Disputes of Gifted Employees. Gifted and Talented $\quad$ International, $\quad$ 163-172. https://doi.org/10.1080/15332276.2013.11678411

Vincent, A., Ross, D., \& Williams, A. (2002). Using the Multiple Intelligences Theory in International Business. Journal of Teaching in International Business, 14(1), 45-63. https:// doi.org/10.1300/J066v14n01_04

Zeidner, M., Matthews, G., \& Roberts, R. D. (2004). Emotional Intelligence in the Workplace: A Critical Review. Applied Psychology, 53(3), 371-399. 


\section{Appendix A}

\section{Description of MIDAS ${ }^{\mathrm{TM}}$ scales and subscales}

\section{Scale}

\section{Linguistic}

- Expressive sensitivity

- Rhetorical skill

- Writing

\section{Interpersonal}

- Social persuasion

- Social sensitivity

- Interpersonal work

\section{Intrapersonal}

- Personal knowledge / efficacy

- Calculations

- Spatial problem solving

- Effectiveness

\section{Logical-Mathematical}

- School Math

- Strategy games

- Everyday math

- Everyday problem solving

\section{Description}

To think in words and to use language to express and understand complex meanings. Sensitivity to the meaning of words and the order among words, sounds, rhythms, inflections. To reflect on the use of language in everyday life.

skill in the use of words for expressive and practical purposes.

to use language effectively for interpersonal negotiation and persuasion

to use words well in writing reports, letters, stories, verbal memory, reading / writing

To think about and understand another person. To have empathy and recognize distinctions among people and to appreciate their perspectives with sensitivity to their motives, moods and intentions. It involves interacting effectively with one or more people in familiar, casual or working circumstances.

ability for influencing other people

sensitivity to and understanding of other people's moods, feelings and point of view

interest and skill for jobs involving working with people

To think about and understand one's self. To be aware of one's strengths and weaknesses and to plan effectively to achieve personal goals. Reflecting on and monitoring one's thoughts and feelings and regulating them effectively. The ability to monitor one's self in interpersonal relationships and to act with personal efficacy.

awareness of one's own ideas, abilities; able to achieve personal goals

meta-cognition 'thinking about thinking' involving numerical operations.

self awareness to problem solving, while moving self or objects through space.

ability to relate oneself well to others and manage personal relationships.

To think of cause and effect connections and to understand relationships among actions, objects or ideas. To calculate, quantify or consider propositions and perform complex mathematical or logical operations. It involves inductive and deductive reasoning skills as well as critical and creative problem-solving.

effective application of the learned (methodical) school calculations

good at games of skill and strategy

using math effectively in everyday life

able to use logical reasoning to solve everyday problems, curiosity

To think in pictures and to perceive the visual world accurately. To think in three-dimensions and to transform one's perceptions and re-create aspects of one's visual experience via imagination. To work with objects effectively. 
Scale

- Spatial awareness

- Artistic design

- Working with objects

\section{Musical}

- Appreciation

- Instrumental skill

- Vocal ability

- Composition

\section{Kinesthetic}

- Athletic

- Dexterity

\section{Naturalistic}

- Science

- Animals

- Plants
Description

to solve problems of spatial orientation and moving objects through space such as driving a car.

to create artistic designs, drawings, paintings or other crafts.

to make, build, fix, or assemble things.

To think in sounds, rhythms, melodies and rhymes. To be sensitive to pitch, rhythm, timbre and tone. To recognize, create and reproduce music by using an instrument or voice. Active listening and a strong connection between music and emotions.

actively enjoys listening to music of some kind.

skill and experience in playing a musical instrument.

a good voice for singing in tune and in harmony.

makes up songs or poetry and has tunes on his/her mind.

To think in movements and to use the body in skilled and complicated ways for expressive and goal directed activities. A sense of timing, coordination for whole body movement and the use of hands for manipulating objects.

ability to move the whole body for physical activities such as balancing, coordination and sports

to use the hands with dexterity and skill for detailed activities and expressive moment.

To understand the natural world including plants, animals and scientific studies. To recognize, name and classify individuals, species and ecological relationships. To interact effectively with living creatures and discern patterns of life \& natural forces.

knowledge of natural living energy forces including cooking, weather and physics.

skill for understanding animal behavior, needs, characteristics

ability to work with plants, i.e., gardening, farming and horticulture.

Adapted from Shearer (1996) and the MIDAS ${ }^{\text {TM }}$ Online Management System 


\section{Appendix B}

\section{Table 1}

Correlations between MIDAS ${ }^{\mathrm{TM}}$ main- and subscales and the KEYS®

\begin{tabular}{|c|c|c|c|c|c|c|c|c|c|c|c|c|}
\hline & & 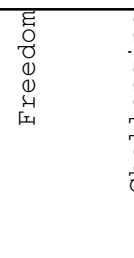 & 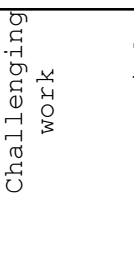 & 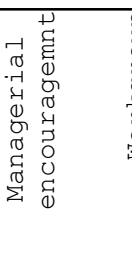 & 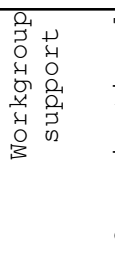 & 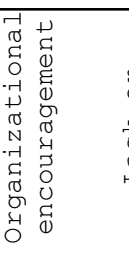 & 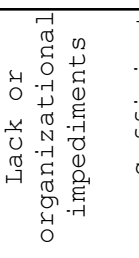 & 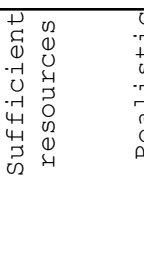 & 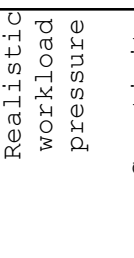 & 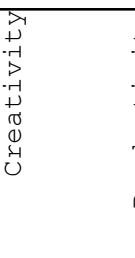 & 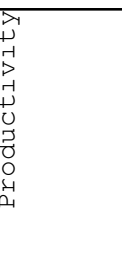 & 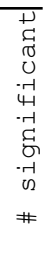 \\
\hline \multirow[t]{2}{*}{$\overline{\text { MUSICAL }}$} & & $r-0,046$ & $-0,046$ & $-0,030$ & 0,009 & $-0,097$ & $-0,110$ & $-0,032$ & $-0,081$ & 0,053 & 0,096 & \\
\hline & sign. & . 0,526 & 0,528 & 0,681 & 0,903 & 0,182 & 0,133 & 0,664 & 0,266 & 0,465 & 0,191 & \\
\hline Musical & & $r-0,111$ & $-0,063$ & $-0,030$ & 0,027 & $-0,118$ &,$- 151 \star$ & $-0,057$ & $-0,106$ & 0,052 & 0,047 & \\
\hline appreciation & sign. & . 0,128 & 0,390 & 0,681 & 0,710 & 0,107 & 0,038 & 0,442 & 0,148 & 0,479 & 0,525 & \\
\hline Instrumental & & $r-0,010$ & $-0,003$ & $-0,037$ & 0,049 & $-0,107$ & $-0,097$ & $-0,045$ & $-0,096$ & 0,063 & 0,116 & \\
\hline skill & sign. & . 0,897 & 0,962 & 0,610 & 0,502 & 0,145 & 0,183 & 0,540 & 0,191 & 0,390 & 0,113 & \\
\hline \multirow[t]{2}{*}{ Vocal abiiity } & & $r-0,008$ & $-0,072$ & $-0,017$ & $-0,033$ & $-0,041$ & $-0,035$ & 0,017 & 0,007 & $-0,032$ &, $144 *$ & \\
\hline & ign. & . 0,910 & 0,326 & 0,820 & 0,654 & 0,580 & 0,633 & 0,813 & 0,922 & 0,666 & 0,048 & \\
\hline \multirow[t]{2}{*}{ Composing } & $r$ & $r \quad 0,053$ & 0,060 & $-0,020$ & $-0,022$ & $-0,039$ & $-0,040$ & $-0,014$ & $-0,067$ &, $149 *$ & $-0,015$ & \\
\hline & ign. & . 0,465 & 0,413 & 0,783 & 0,761 & 0,595 & 0,585 & 0,851 & 0,359 & 0,041 & 0,841 & \\
\hline \multirow[t]{2}{*}{ KINESTHETIC } & $r$ & $r \quad 0,000$ & 0,050 & $-0,096$ & $-0,027$ & $-0,080$ &,$- 158 *$ & 0,008 & 0,007 & 0,111 & $-0,029$ & \\
\hline & ign. & . 1,000 & 0,491 & 0,188 & 0,714 & 0,275 & 0,030 & 0,912 & 0,929 & 0,129 & 0,698 & \\
\hline \multirow[t]{2}{*}{ Athletic } & & $r-0,029$ & $-0,006$ &,$- 170 *$ & $-0,081$ & $-0,130$ & $-0,132$ & $-0,018$ & 0,015 & 0,005 & $-0,114$ & \\
\hline & ign. & . 0,694 & 0,932 & 0,019 & 0,267 & 0,075 & 0,070 & 0,804 & 0,839 & 0,948 & 0,119 & \\
\hline \multirow[t]{2}{*}{ Dexterity } & & $r \quad 0,030$ & 0,093 & 0,003 & 0,045 & $-0,007$ & $-0,139$ & $-0,001$ & $-0,022$ &, $180 *$ & 0,077 & \\
\hline & ign. & $. \quad 0,684$ & 0,205 & 0,973 & 0,536 & 0,925 & 0,057 & 0,993 & 0,767 & 0,013 & 0,294 & \\
\hline LOGICAL- & & $r \quad 0,035$ &, $152 *$ & $-0,033$ & 0,019 & $-0,089$ &,$- 253 * \star$ & $-0,019$ &,$- 206 * *$ &, $155 *$ & 0,069 & 4 \\
\hline MATHEMATICAL & ign. & $.0,631$ & 0,037 & 0,649 & 0,797 & 0,223 & 0,000 & 0,794 & 0,005 & 0,033 & 0,345 & \\
\hline \multirow[t]{2}{*}{ School Math } & & $r \quad 0,057$ & 0,077 & $-0,058$ & 0,065 & $-0,056$ & $-0,116$ & 0,006 & $-0,071$ & 0,135 & 0,073 & 0 \\
\hline & sign. & . 0,439 & 0,293 & 0,428 & 0,377 & 0,441 & 0,113 & 0,936 & 0,329 & 0,064 & 0,317 & \\
\hline \multirow[t]{2}{*}{ Logic games } & & $r \quad 0,047$ &, $227 * \star$ & 0,078 & 0,109 & 0,022 & $-0,126$ & 0,137 & $-0,061$ &, $197 * \star$ & 0,121 & 2 \\
\hline & sign. & . 0,524 & 0,002 & 0,286 & 0,135 & 0,762 & 0,084 & 0,062 & 0,404 & 0,007 & 0,098 & \\
\hline \multirow[t]{2}{*}{ Everyday math } & & $r-0,025$ & 0,068 & $-0,091-$ & $-0,093$ & $-0,081$ &,$- 258 * *$ & $-0,005$ &,$- 203 * \star$ & 0,084 & 0,037 & \\
\hline & ign. & 0,737 & 0,353 & 0,215 & 0,204 & 0,269 & 0,000 & 0,945 & 0,005 & 0,250 & 0,619 & \\
\hline \multirow[t]{2}{*}{ Problem solving } & & $r-0,028$ &, $163 *$ & $0,008-$ & $-0,019$ & $-0,078$ &,$- 204 * *$ & $-0,092$ &,$- 190 * *$ &, $168 *$ & 0,028 & 4 \\
\hline & sign. & 0,705 & 0,025 & 0,918 & 0,798 & 0,288 & 0,005 & 0,210 & 0,009 & 0,021 & 0,707 & \\
\hline \multirow[t]{2}{*}{ VISUAL-SPATIAL } & & $r \quad 0,027$ &, $185 *$ & 0,059 & 0,093 & 0,045 &,$- 169 *$ & $-0,047$ &,$- 177 *$ &, $252 * \star$ & 0,078 & 4 \\
\hline & sign. & 0,715 & 0,011 & 0,417 & 0,204 & 0,543 & 0,020 & 0,525 & 0,015 & 0,000 & 0,287 & \\
\hline Spacial & & $r \quad 0,065$ & 0,138 & 0,064 &, $146 *$ & 0,083 & $-0,121$ & $-0,045$ &,$- 153 *$ & 0,132 & 0,084 & \\
\hline awareness & sign. & . 0,373 & 0,058 & 0,380 & 0,045 & 0,256 & 0,097 & 0,544 & 0,036 & 0,070 & 0,251 & \\
\hline \multirow[t]{2}{*}{ Artistic design } & & $r-0,027$ & 0,121 & 0,041 & 0,018 & 0,017 & $-0,135$ & $-0,030$ & $-0,068$ &, $235 * \star$ & 0,049 & 1 \\
\hline & sign. & . 0,714 & 0,097 & 0,574 & 0,805 & 0,819 & 0,064 & 0,681 & 0,355 & 0,001 & 0,501 & \\
\hline Manipulate & & $r \quad 0,014$ &, $177 *$ & $-0,015$ & 0,083 & $-0,021$ &,$- 183 \star$ & $-0,006$ &,$- 206 * \star$ &, $161 *$ & 0,043 & 4 \\
\hline objects & sign. & . 0,848 & 0,015 & 0,837 & 0,258 & 0,773 & 0,012 & 0,939 & 0,004 & 0,027 & 0,557 & \\
\hline \multirow[t]{2}{*}{ LINGUISTIC } & & $r \quad 0,034$ &, $198 * *$ & $-0,046$ & 0,033 & $-0,093$ & $-0,093$ & $-0,044$ &,$- 196 * \star$ &, $157 *$ & $-0,002$ & \\
\hline & sign. & 0,641 & 0,006 & 0,531 & 0,649 & 0,204 & 0,202 & 0,550 & 0,007 & 0,031 & 0,982 & \\
\hline Expressive & & $r-0,015$ & 0,133 & $-0,044$ & 0,001 & $-0,097$ & $-0,092$ & $-0,081$ &,$- 187 \star$ & 0,129 & $-0,037$ & \\
\hline sensitivity & sign. & . 0,833 & 0,069 & 0,550 & 0,992 & 0,186 & 0,206 & 0,271 & 0,010 & 0,076 & 0,611 & \\
\hline Rhetorical & & $r \quad 0,092$ &, $264 * \star$ & 0,001 & 0,031 & $-0,039$ & $-0,089$ & $-0,008$ &,$- 157 *$ &, $188 * \star$ & 0,041 & \\
\hline skill & sign. & . 0,206 & 0,000 & 0,993 & 0,669 & 0,591 & 0,225 & 0,918 & 0,031 & 0,010 & 0,579 & \\
\hline
\end{tabular}




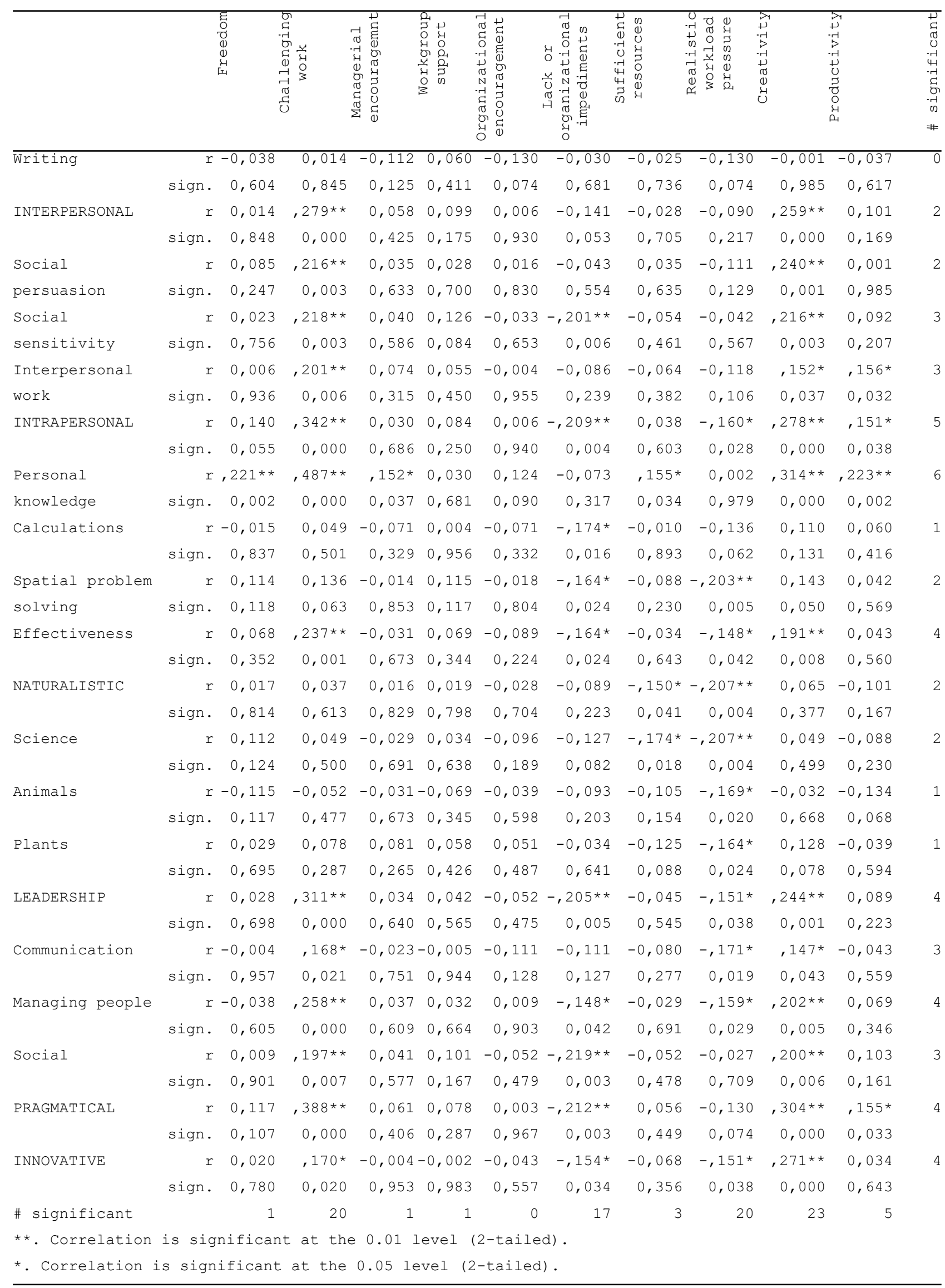




\section{Table 2}

Statistics for KEYS® variables grouped by yes or no predominant innovative intellectual style

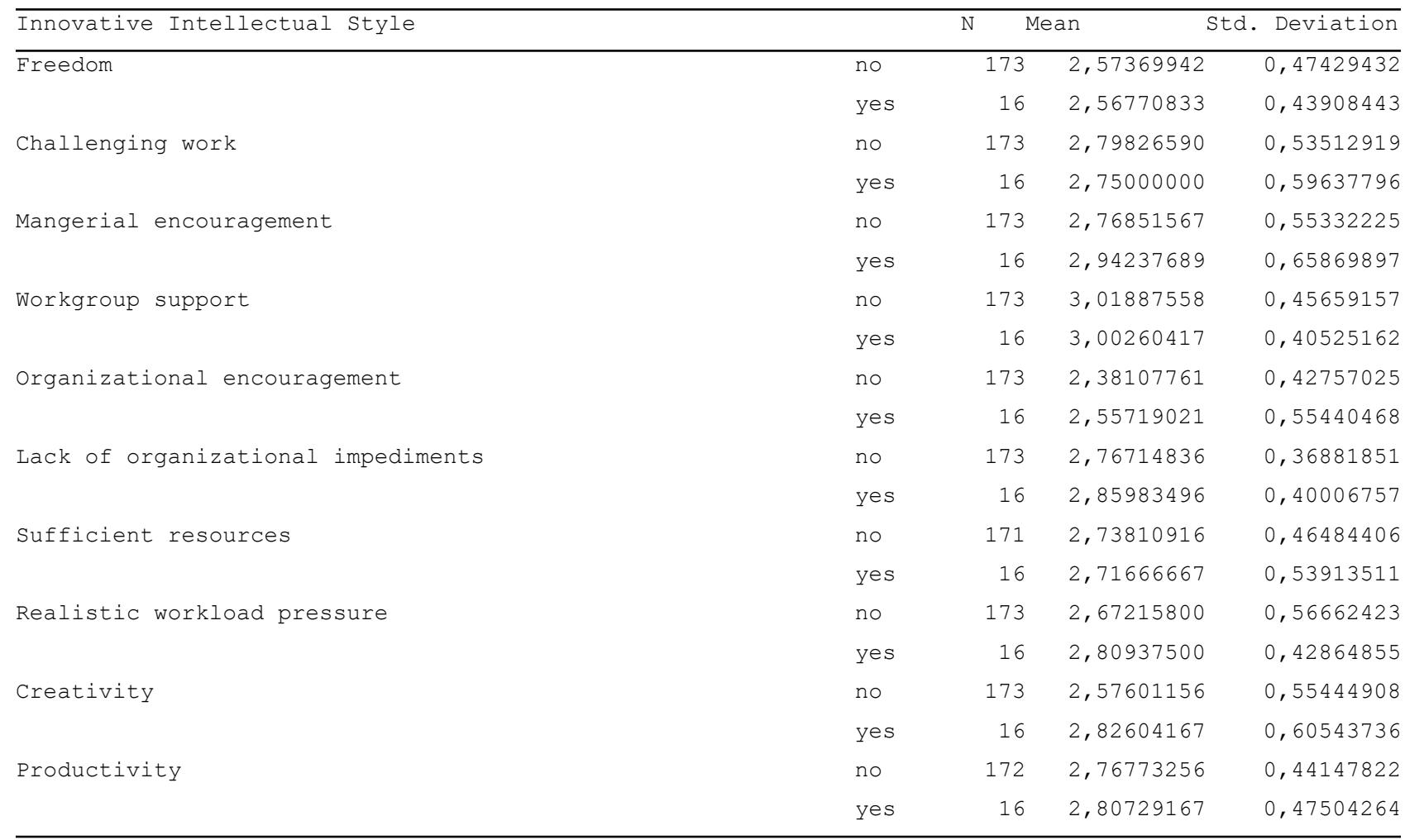

Table 3

Frequencies of MI-profiles with intelligence $x$ as highest-or lowest point

\begin{tabular}{|c|c|c|c|c|}
\hline \multirow[b]{2}{*}{ Intelligence $\mathrm{x}$} & \multicolumn{2}{|c|}{ High point } & \multicolumn{2}{|c|}{ Low point } \\
\hline & Frequency & Percentage & Frequency & Percentage \\
\hline Interpersonal & 65 & 34,8 & 5 & 2,7 \\
\hline Intrapersonal & 10 & 5,3 & 2 & 1,1 \\
\hline Kinesthetic & 15 & 8,0 & 26 & 13,9 \\
\hline Linguistic & 37 & 19,8 & 6 & 3,2 \\
\hline Logical-Mathematical & 4 & 2,1 & 22 & 11,8 \\
\hline Musical & 13 & 7,0 & 73 & 39,0 \\
\hline Naturalistic & 28 & 15,0 & 35 & 18,7 \\
\hline Visual-Spatial & 15 & 8,0 & 18 & 9,6 \\
\hline TOTAL & 187 & 100,0 & 187 & 100,0 \\
\hline
\end{tabular}




\section{Table 4}

Difference between means of KEYS® variables between the group with intelligence $x$ as highest versus the group with intelligence $x$ not as highest

\begin{tabular}{|c|c|c|c|c|}
\hline$\overline{\text { HIGHPOINT }}$ & KEYS@ & highest & not as & $\mathrm{p}$ \\
\hline & & & highest & \\
\hline$\overline{M U S I C A L}$ & Freedom & 2,4487 & 2,5862 & 0,1543 \\
\hline & Challenging work & 2,5692 & 2,8086 & 0,1170 \\
\hline & Managerial encouragement & 2,6573 & 2,7901 & 0,3305 \\
\hline & Workgroup support & 2,9299 & 3,0147 & 0,4496 \\
\hline & Organizational encouragement & 2,2610 & 2,3934 & 0,2945 \\
\hline & Lack of organizational impediments & 2,7870 & 2,7729 & 0,8952 \\
\hline & Sufficient resources & 2,6615 & 2,7419 & 0,5456 \\
\hline & Realistic workload pressure & 2,7692 & 2,6757 & 0,5936 \\
\hline & Creativity & 2,3795 & 2,6088 & 0,1498 \\
\hline & Productivity & 2,6667 & 2,7776 & 0,3753 \\
\hline KINESTHETIC & Freedom & 2,5111 & 2,5824 & 0,5185 \\
\hline & Challenging work & 2,6667 & 2,8029 & 0,4291 \\
\hline & Managerial encouragement & 2,6530 & 2,7921 & 0,4061 \\
\hline & Workgroup support & 2,9075 & 3,0176 & 0,3045 \\
\hline & Organizational encouragement & 2,3766 & 2,3848 & 0,9277 \\
\hline & Lack of organizational impediments & 2,8264 & 2,7693 & 0,5239 \\
\hline & Sufficient resources & 2,8644 & 2,7251 & 0,3196 \\
\hline & Realistic workload pressure & 2,7133 & 2,6795 & 0,7840 \\
\hline & Creativity & 2,6222 & 2,5903 & 0,7455 \\
\hline & Productivity & 2,7600 & 2,7707 & 0,9258 \\
\hline LOGICAL-MATHEMATICAL & Freedom & 2,6250 & 2,5756 & 0,7827 \\
\hline & Challenging work & 3,0500 & 2,7863 & 0,0619 \\
\hline & Managerial encouragement & 3,0597 & 2,7748 & 0,3330 \\
\hline & Workgroup support & 3,0536 & 3,0078 & 0,8291 \\
\hline & Organizational encouragement & 2,4917 & 2,3818 & 0,5212 \\
\hline & Lack of organizational impediments & 2,4808 & 2,7803 & 0,1408 \\
\hline & Sufficient resources & 2,7667 & 2,7356 & 0,7598 \\
\hline & Realistic workload pressure & 2,2750 & 2,6911 & 0,2648 \\
\hline & Creativity & 2,9583 & 2,5849 & 0,0296 \\
\hline & Productivity & 2,9167 & 2,7667 & 0,2608 \\
\hline VISUAL-SPATIAL & Freedom & 2,6333 & 2,5717 & 0,7240 \\
\hline & Challenging work & 2,7467 & 2,7959 & 0,7785 \\
\hline & Managerial encouragement & 2,8661 & 2,7735 & 0,5010 \\
\hline & Workgroup support & 3,0355 & 3,0064 & 0,7990 \\
\hline & Organizational encouragement & 2,5469 & 2,3700 & 0,1695 \\
\hline & Lack of organizational impediments & 2,7987 & 2,7718 & 0,7842 \\
\hline & Sufficient resources & 2,7889 & 2,7317 & 0,7190 \\
\hline & Realistic workload pressure & 2,6467 & 2,6853 & 0,8075 \\
\hline & Creativity & 2,6556 & 2,5874 & 0,7095 \\
\hline & Productivity & 2,7911 & 2,7680 & 0,8438 \\
\hline LINGUISTIC & Freedom & 2,6554 & 2,5572 & 0,2975 \\
\hline & Challenging work & 2,9554 & 2,7517 & 0,0311 \\
\hline & Managerial encouragement & 2,7244 & 2,7949 & 0,5104 \\
\hline
\end{tabular}




\begin{tabular}{|c|c|c|c|c|}
\hline \multirow[t]{2}{*}{$\overline{\mathrm{HIGHPOINT}}$} & \multirow[t]{2}{*}{ KEYS® } & highest & not as & $\mathrm{p}$ \\
\hline & & \multicolumn{3}{|c|}{ highest } \\
\hline \multirow{17}{*}{ INTERPERSONAL } & Workgroup support & 2,9432 & 3,0249 & 0,3518 \\
\hline & Organizational encouragement & 2,3494 & 2,3928 & 0,5883 \\
\hline & Lack of organizational impediments & 2,8017 & 2,7671 & 0,6262 \\
\hline & Sufficient resources & 2,8279 & 2,7137 & 0,1818 \\
\hline & Realistic workload pressure & 2,6063 & 2,7009 & 0,3206 \\
\hline & Creativity & 2,6721 & 2,5733 & 0,4087 \\
\hline & Productivity & 2,8599 & 2,7477 & 0,1178 \\
\hline & Freedom & 2,5974 & 2,5656 & 0,6503 \\
\hline & Challenging work & 2,8731 & 2,7488 & 0,1268 \\
\hline & Managerial encouragement & 2,8498 & 2,7442 & 0,2051 \\
\hline & Workgroup support & 3,1146 & 2,9524 & 0,0152 \\
\hline & Organizational encouragement & 2,4053 & 2,3729 & 0,6047 \\
\hline & Lack of organizational impediments & 2,7803 & 2,7705 & 0,8637 \\
\hline & Sufficient resources & 2,7269 & 2,7413 & 0,8354 \\
\hline & Realistic workload pressure & 2,7397 & 2,6515 & 0,3077 \\
\hline & Creativity & 2,6864 & 2,5430 & 0,0701 \\
\hline & Productivity & 2,8028 & 2,7523 & 0,4531 \\
\hline \multirow[t]{10}{*}{ INTRAPERSONAL } & Freedom & 2,6333 & 2,5734 & 0,5971 \\
\hline & Challenging work & 2,6350 & 2,8008 & 0,1412 \\
\hline & Managerial encouragement & 2,5939 & 2,7915 & 0,2377 \\
\hline & Workgroup support & 2,8833 & 3,0159 & 0,1708 \\
\hline & Organizational encouragement & 2,2892 & 2,3895 & 0,4483 \\
\hline & Lack of organizational impediments & 2,6520 & 2,7808 & 0,3824 \\
\hline & Sufficient resources & 2,7467 & 2,7357 & 0,9171 \\
\hline & Realistic workload pressure & 2,7000 & 2,6812 & 9,9335 \\
\hline & Creativity & 2,2933 & 2,6098 & 0,0234 \\
\hline & Productivity & 2,6117 & 2,7788 & 0,4259 \\
\hline \multirow[t]{10}{*}{ NATURALISTIC } & Freedom & 2,4613 & 2,5970 & 0,2145 \\
\hline & Challenging work & 2,6018 & 2,8255 & 0,0652 \\
\hline & Managerial encouragement & 2,8030 & 2,7770 & 0,8471 \\
\hline & Workgroup support & 2,9647 & 3,0165 & 0,6540 \\
\hline & Organizational encouragement & 2,3737 & 2,3860 & 0,9114 \\
\hline & Lack of organizational impediments & 2,7606 & 2,7763 & 0,8485 \\
\hline & Sufficient resources & 2,5667 & 2,7661 & 0,0896 \\
\hline & Realistic workload pressure & 2,6625 & 2,6856 & 0,8249 \\
\hline & Creativity & 2,3756 & 2,6311 & 0,0454 \\
\hline & Productivity & 2,6518 & 2,7907 & 0,2103 \\
\hline
\end{tabular}

\section{Welch Two Sample t-test}




\section{Table 5}

Difference between means of KEYS® variables between the group with intelligence $x$ as lowest versus the group with intelligence $x$ not as lowest

\begin{tabular}{|c|c|c|c|c|}
\hline \multirow[t]{2}{*}{$\overline{\text { LOWPOINT }}$} & \multirow[t]{2}{*}{ KEYS® } & \multirow[t]{2}{*}{ lowest } & \multicolumn{2}{|l|}{ not as } \\
\hline & & & lowest & \\
\hline \multirow[t]{10}{*}{$\overline{\text { MUSICAL }}$} & Freedom & 2,6301 & 2,5424 & 0,2077 \\
\hline & Challenging work & 2,8425 & 2,7596 & 0,2870 \\
\hline & Managerial encouragement & 2,7882 & 2,7762 & 0,8873 \\
\hline & Workgroup support & 2,9707 & 3,0331 & 0,3646 \\
\hline & Organizational encouragement & 2,4152 & 2,3643 & 0,4246 \\
\hline & Lack of organizational impediments & 2,7966 & 2,7594 & 0,4935 \\
\hline & Sufficient resources & 2,7000 & 2,7595 & 0,4083 \\
\hline & Realistic workload pressure & 2,6511 & 2,7020 & 0,5196 \\
\hline & Creativity & 2,6167 & 2,5776 & 0,6195 \\
\hline & Productivity & 2,6705 & 2,8335 & 0,0168 \\
\hline \multirow[t]{10}{*}{ KINESTHETIC } & Freedom & 2,6827 & 2,5595 & 0,2619 \\
\hline & Challenging work & 2,9635 & 2,7643 & 0,1159 \\
\hline & Managerial encouragement & 2,9272 & 2,7573 & 0,2320 \\
\hline & Workgroup support & 3,1250 & 2,9900 & 0,1443 \\
\hline & Organizational encouragement & 2,4388 & 2,3754 & 0,5544 \\
\hline & Lack of organizational impediments & 2,7495 & 2,7779 & 0,7635 \\
\hline & Sufficient resources & 2,8051 & 2,7252 & 0,3407 \\
\hline & Realistic workload pressure & 2,5212 & 2,7082 & 0,1249 \\
\hline & Creativity & 2,7885 & 2,5613 & 0,1302 \\
\hline & Productivity & 2,9346 & 2,7433 & 0,0365 \\
\hline \multirow[t]{10}{*}{ LOGICAL-MATHEMATICAL } & Freedom & 2,5303 & 2,5828 & 0,5679 \\
\hline & Challenging work & 2,7136 & 2,8024 & 0,3964 \\
\hline & Managerial encouragement & 2,8144 & 2,7765 & 0,7562 \\
\hline & Workgroup support & 2,9667 & 3,0144 & 0,6132 \\
\hline & Organizational encouragement & 2,3564 & 2,3879 & 0,6844 \\
\hline & Lack of organizational impediments & 2,7796 & 2,7732 & 0,9302 \\
\hline & Sufficient resources & 2,5992 & 2,7545 & 0,0824 \\
\hline & Realistic workload pressure & 2,6068 & 2,6922 & 0,4206 \\
\hline & Creativity & 2,5939 & 2,5927 & 0,9915 \\
\hline & Productivity & 2,6886 & 2,7807 & 0,2731 \\
\hline \multirow[t]{10}{*}{ VISUAL-SPATIAL } & Freedom & 2,4676 & 2,5883 & 0,3675 \\
\hline & Challenging work & 2,5694 & 2,8157 & 0,0788 \\
\hline & Managerial encouragement & 2,6216 & 2,7979 & 0,1304 \\
\hline & Workgroup support & 2,9825 & 3,0117 & 0,7974 \\
\hline & Organizational encouragement & 2,1704 & 2,4069 & 0,0295 \\
\hline & Lack of organizational impediments & 2,7329 & 2,7783 & 0,6937 \\
\hline & Sufficient resources & 2,7759 & 2,7321 & 0,6842 \\
\hline & Realistic workload pressure & 2,7491 & 2,6750 & 0,6122 \\
\hline & Creativity & 2,2278 & 2,6318 & 0,0107 \\
\hline & Productivity & 2,6944 & 2,7779 & 0,4160 \\
\hline \multirow[t]{3}{*}{ LINGUISTIC } & Freedom & 2,7222 & 2,5718 & 0,6481 \\
\hline & Challenging work & 3,0667 & 2,7829 & 0,3829 \\
\hline & Managerial encouragement & 2,9438 & 2,7755 & 0,5567 \\
\hline
\end{tabular}




\begin{tabular}{|c|c|c|c|c|}
\hline \multirow[t]{2}{*}{$\overline{\text { LOWPOINT }}$} & \multirow[t]{2}{*}{ KEYS® } & \multirow[t]{2}{*}{ lowest } & \multirow{2}{*}{$\begin{array}{l}\text { not as } \\
\text { lowest }\end{array}$} & $\overline{\mathrm{p}}$ \\
\hline & & & & \\
\hline \multirow{17}{*}{ INTERPERSONAL } & Workgroup support & 2,9855 & 3,0095 & 0,9203 \\
\hline & Organizational encouragement & 2,5329 & 2,3792 & 0,4656 \\
\hline & Lack of organizational impediments & 2,7500 & 2,7747 & 0,9075 \\
\hline & Sufficient resources & 3,0667 & 2,7253 & 0,2584 \\
\hline & Realistic workload pressure & 2,6167 & 2,6843 & 0,8402 \\
\hline & Creativity & 2,8222 & 2,5853 & 0,2398 \\
\hline & Productivity & 3,3722 & 2,7499 & 0,0085 \\
\hline & Freedom & 2,7000 & 2,5733 & 0,6742 \\
\hline & Challenging work & 2,4400 & 2,8016 & 0,3525 \\
\hline & Managerial encouragement & 2,7073 & 2,7829 & 0,8407 \\
\hline & Workgroup support & 3,2643 & 3,0018 & 0,3339 \\
\hline & Organizational encouragement & 2,5614 & 2,3793 & 0,6362 \\
\hline & Lack of organizational impediments & 2,9221 & 2,7699 & 0,5674 \\
\hline & Sufficient resources & 2,8667 & 2,7327 & 0,7260 \\
\hline & Realistic workload pressure & 2,9100 & 2,6759 & 0,3745 \\
\hline & Creativity & 2,3967 & 2,5983 & 0,6372 \\
\hline & Productivity & 2,8167 & 2,7686 & 0,8724 \\
\hline \multirow[t]{10}{*}{ INTRAPERSONAL } & Freedom & 1,6250 & 2,5869 & 0,0649 \\
\hline & Challenging work & 1,5000 & 2,8059 & 0,0257 \\
\hline & Managerial encouragement & 2,8377 & 2,7803 & 0,2181 \\
\hline & Workgroup support & 2,7500 & 3,0116 & 0,4837 \\
\hline & Organizational encouragement & 1,9000 & 2,3894 & 0,1026 \\
\hline & Lack of organizational impediments & 2,9583 & 2,7719 & 0,3672 \\
\hline & Sufficient resources & 2,2500 & 2,7415 & 0,6306 \\
\hline & Realistic workload pressure & 2,7000 & 2,6820 & 0,9912 \\
\hline & Creativity & 1,3500 & 2,6063 & 0,0597 \\
\hline & Productivity & 2,3333 & 2,7746 & 0,4103 \\
\hline \multirow[t]{10}{*}{ NATURALISTIC } & Freedom & 2,4833 & 2,5981 & 0,1218 \\
\hline & Challenging work & 2,8000 & 0,2021 & 0,9184 \\
\hline & Managerial encouragement & 2,6973 & 2,8002 & 0,2660 \\
\hline & Workgroup support & 3,0245 & 3,0052 & 0,7969 \\
\hline & Organizational encouragement & 2,3830 & 2,3844 & 0,9831 \\
\hline & Lack of organizational impediments & 2,7347 & 2,7830 & 0,4457 \\
\hline & Sufficient resources & 2,7790 & 2,7264 & 0,5306 \\
\hline & Realistic workload pressure & 2,8571 & 2,6419 & 0,0441 \\
\hline & Creativity & 2,6448 & 2,5809 & 0,4743 \\
\hline & Productivity & 2,8595 & 2,7492 & 0,1257 \\
\hline
\end{tabular}

\section{Welch Two Sample t-test, two sided}




\section{Table 6}

Euclidean distances between personal profile and job profile, correlated with the KEYS®

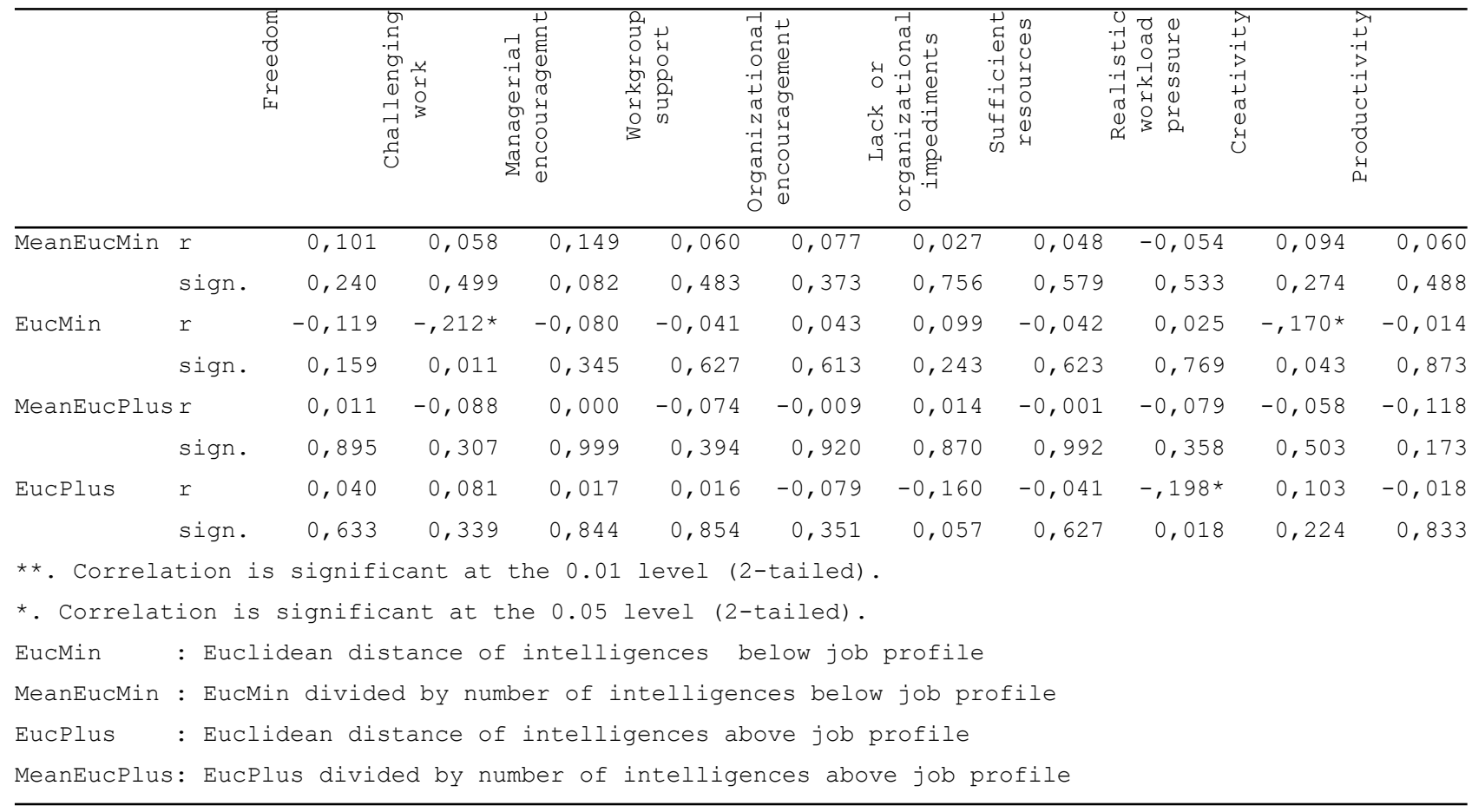

